\title{
THE EFFECTS OF TREATMENT WITH MELATONIN ON THE ULTRASTRUCTURE OF MOUSE LEYDIG CELLS: A QUANTITATIVE STUDY
}

\author{
REDINS, C. A., ${ }^{1}$ REDINS, G. M. ${ }^{2}$ and NOVAES, J. C. ${ }^{1}$ \\ ${ }^{1}$ Departamento de Morfologia, Centro Biomédico, Universidade Federal do Espírito Santo, \\ CEP 29040-090, Vitória, ES, Brazil \\ ${ }^{2}$ Bolsista de Iniciação Científica do CNPq \\ Correspondence to: Carlos Alberto Redins, Rua Cyro Lima, 45, Enseada do Suá, \\ CEP 29050-230, Vitória, ES, Brazil, e-mail: redins@npd.ufes.br \\ Received April 5, 2001 - Accepted October 23, 2001 - Distributed August 31, 2002
}

(With 3 figures)

\begin{abstract}
Both the presence of receptors for gonadal steroids in the pineal gland and in vitro observations of direct action of melatonin upon Leydig cells, inhibiting testosterone secretion, indicate a direct connection between pineal gland and gonadal function. In the present study, we used a transmission electron microscope to analyze the morphologic parameters of Leydig cells from adult Swiss outbred white mice treated with daily subcutaneous injections of $100 \mu \mathrm{g}$ of melatonin (N-acetyl, 5methoxytryptamine), during 22 consecutive days, compared with sham-control animals which had only received the melatonin vehicle. The melatonin group of mice showed a decrease in nuclear volume and fractional nuclear volume; smooth and rough endoplasmic reticulum; mitochondria; and Golgi complex. Our data also showed an increase in cytoplasmic volume, fractional cytoplasmic volume, and lysosomes in these same animals. The results suggest that melatonin, directly or indirectly, alters the ultrastructure of mouse Leydig cells and possibly influences their secretory activity by inhibiting their capacity to secrete steroids.
\end{abstract}

Key words: Leydig cell, melatonin, ultrastructure, testis, reproduction.

\section{RESUMO}

Efeito do tratamento com melatonina sobre a ultra-estrutura das células de Leydig do camundongo: estudo quantitativo

No presente trabalho, utilizamos a microscopia eletrônica de transmissão para analisar os parâmetros morfológicos das células de Leydig de camundongos adultos, suíços outbred, tratados com uma injeção subcutânea diária de $100 \mu \mathrm{g}$ de melatonina (5-metoxi-N-acetil-triptamina), durante 22 dias consecutivos, comparando-os com animais sham-controle que receberam apenas o veículo da melatonina. Os animais tratados com melatonina mostraram diminuição do volume nuclear, da fração volumétrica do núcleo, do retículo endoplasmático liso e rugoso, das mitocôndrias e do complexo de Golgi. Nos mesmos animais ocorreu, também, aumento do volume do citoplasma e da fração volumétrica do citoplasma e dos lisossomos. Esses resultados sugerem que a melatonina pode alterar, direta ou indiretamente, a ultra-estrutura das células de Leydig do camundongo, inibindo sua atividade de síntese, como a produção de esteróides.

Palavras-chave: célula de Leydig, melatonina, ultra-estrutura, testículo, reprodução. 


\section{INTRODUCTION}

A mutual relationship between the pineal gland and testis has been already demonstrated. In vitro observations have demonstrated the direct action of melatonin on the Leydig cells, inhibiting testosterone secretion (Niedziela et al., 1995; Valenti et al., 1995). Valenti et al. (1997) reported the presence of receptors for melatonin in adult rat Leydig cells. In hCG/cAMP analogue treated MA-10 mouse Leydig cells, Wu et al. (2001) observed that melatonin suppressed steroidogenesis through specific binding sites by blocking steroidogenic acute regulatory protein expression. Pinealectomized rats showed Leydig cell hiperactivity with increase in Golgi complex, mitochondria, and smooth endoplasmic reticulum. Contrary effects were observed in rats treated with melatonin for two months (Kus et al., 2000).

In birds with seasonal reproduction we demonstrated ultrastructural changes in the pineal gland which were associated with reproductive activity (Redins et al., 1997). Using exogenous testosterone and castration we observed that steroids exert an inhibitory role upon the secretory activity of pinealocytes in mice (Novaes et al., 1998; Redins et al., 1999).

In the present research we intend to evaluate, through morphometric studies, the secretory activity of Leydig cells, in mice treated with melatonin, in order to establish the role of this hormone in the functional activity of these cells.

\section{MATERIAL AND METHODS}

Ten adult Swiss "outbred" male mice, were separated into two groups of five animals. In the experimental group, daily at 10:00 a.m. the animals received subcutaneous melatonin (Sigma) injections of $100 \mu \mathrm{g}$ in $0.1 \mathrm{ml}$ of vehicle (5\% alcoholic saline) during 22 consecutive days, according to Lang et al. (1984). The sham-control group animals received, daily at 10:00 a.m., s.c. vehicle injections of $0.1 \mathrm{ml}$ during 22 consecutive days. During the experiment, the mice were housed five to a cage and maintained under laboratory conditions of controlled temperature $\left(25^{\circ} \mathrm{C}\right)$ and lighting $(12 \mathrm{~h}$ of light, $12 \mathrm{~h}$ of darkness). The animals received mouse chow and water ad libitum. They were killed by cervical decapitation under ether anesthesia and the two testes were immediately removed and rapidly flooded with Karnovsky's fixative solution (0.8\% paraformaldehyde and $1.5 \%$ glutaraldehyde in $0.2 \mathrm{M}$ cacodylate buffer at $\mathrm{pH} 7.4$ ). The testes were sliced into small sections which were immersed again in Karnovsky's fixative solution for one hour. They were then post-fixed in $1 \%$ osmium tetroxide solution for $1 \mathrm{~h}$; buffered at $\mathrm{pH}$ 7.4 with Na-cacodylate $(0.1 \mathrm{M})$; subsequently dehydrated in an ascending sequence of ethanol and acetone; and embedded in Epon 812. Sections were then stained with uranyl acetate and lead citrate, and were examined and photographed using a Zeiss EM10 electron microscope from the Center for Electron Microscopy, Institute of Biological Sciences, UFMG. We measured the orthogonal diameters $D_{1}$ and $D_{2}$ from 20 to 40 nuclei per animal, randomly distributed, spherical and well delimited, with prominent nucleoli, using a millimeter-ruled transparent plastic scale, which was placed on the photographs. Twenty photographs per group, at a magnification of X2,500 were counted for both sham-control and melatonin groups and the average radius of nuclei $(\mathrm{R})$ was calculated using the formula $R=\sqrt{ } D_{1} \times D_{2} / 2$. In order to determine the nuclear volume $\left(\mathrm{N}_{\mathrm{vol}}\right)$ we used the geometric formula of the sphere's volume $\left(N_{v o l}=4 / 3 \pi R^{3}\right)$. The fractional volumes of nuclei and cytoplasm of Leydig cells were determined by incident point counting methods (Bozzola \& Russel, 1992), using a test system consisting of 414 computerized points randomly distributed on a net-like transparent test overlay, millimeter-ruled, which was placed on photographs. Twenty photographs per animal at a magnification of $\mathrm{X} 2,500$ were counted for both sham-control and melatonin groups. By using the nuclear volume $\left(\mathrm{N}_{\mathrm{vol}}\right)$ and the fractional volume of nucleus $\left(\mathrm{F}_{\mathrm{Nvol}}\right)$ and cytoplasm $\left(\mathrm{F}_{\mathrm{Cvol}}\right)$ of Leydig cells we calculated the ratio between cytoplasm and nucleus $\left(\mathrm{F}_{\mathrm{Cvol}} / \mathrm{F}_{\mathrm{Nvol}}\right)$ and the cytoplasmic volume $\left(\mathrm{C}_{\mathrm{vol}}\right)$ of the cells $\left(\mathrm{C}_{\mathrm{vol}}=\right.$ $\mathrm{N}_{\mathrm{vol}} \times \mathrm{F}_{\mathrm{Cvol}} / \mathrm{F}_{\mathrm{Nvol}}$ ), according to Bassi et al. (1992) and Ferreira et al. (1994). The fractional volumes of the rough endoplasmic reticulum, smooth endoplasmic reticulum, lipid droplets, mitochondria, lysosomes, and Golgi complex of Leydig cells were determined by incident point counting methods (Bozzola \& Russel, 1992), using the same test system already described for leydig cells fractional nuclear volumes and cytoplasm. Ten $18 \mathrm{x}$ $24 \mathrm{~cm}$ photographs at a magnification of X12,500 were examined per animal, both in sham-control 
and melatonin groups. One-way analysis of variance was used to determine significant quantitative group differences. Tukey's $t$ test was used to compare individual mean differences.

\section{RESULTS}

The Leydig cells of mice have a large cytoplasm volume and a prominent circulary-shaped nucleus (Figs. 1, 2, 3). The cytoplasm contains lipid droplets and abundant smooth endoplasmic reticulum, in the form of a network of interconnecting tubules. Concentric membrane whorls are commonly observed (Fig. 2). Mitochondria are abundant and vary in size and shape. Lysosomes of varying sizes and morphologic appearance were also observed in the cytoplasm of Leydig cells. Cisternae of rough endoplasmic reticulum were seen as small groups arranged parallel to each other or distributed loosely in the cytoplasm.

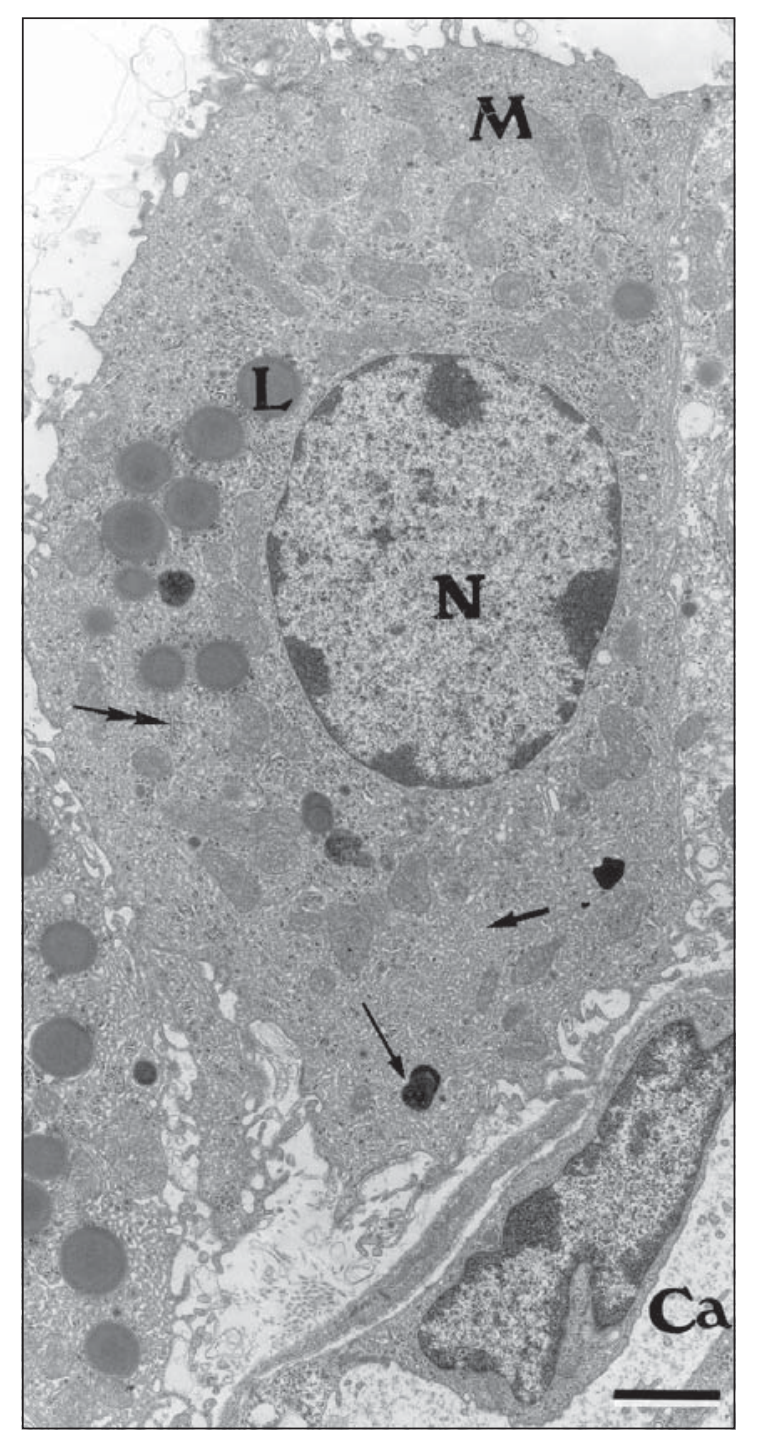

Fig. 1 - An electron micrograph of a sham-control mouse Leydig cell in close association with a blood capillary (Ca). $\mathrm{N}=$ cell nucleus; $\mathrm{M}=$ mitochondria; $\mathrm{L}=$ lipid droplet; thin arrow = lysosome; thick arrow = smooth endoplasmic reticulum; double arrow $=$ rough endoplasmic reticulum. $\mathrm{Bar}=2 \mu \mathrm{m}$. 
The quantitative results observed in Leydig cells in both sham-control and melatonin treated mice are presented in Table 1. The Leydig cells of those treated with melatonin showed a decrease in both nuclear volume and fractional volumes of the nucleus; rough and smooth endoplasmic reticulum; mitochondria; and Golgi complex. We also observed an increase in cytoplasmic volume of Leydig cells, as well as in the fractional volumes of cytoplasm and lysosomes in the same animals. In sham-control mice compared with melatonin treated ones, we report no significant difference in lipid droplet fractional volume.

\section{DISCUSSION}

The nuclear volume of Leydig cells was smaller in mice treated with melatonin. A decrease in the absolute nuclear volume of Leydig cells has been described in hypophysectomized animals (Christensen, 1959), after 28 days of cryptorchidism (Mendis-Handagama et al., 1991) and decrease of hCG doses (Mendis-Handagama et al., 1992). It is well known that the numerous cell types in the body differ greatly in their synthetic activities and, accordingly, in the proportion of chromatin in the active dispersed or extended form. Thus, if chromatin condensation has progressed and the nucleus is quite small (reduced nuclear volume), we can state that in mice treated with melatonin the synthetic activity of Leydig cells is decreased as well.

The smooth endoplasmic reticulum (SER) and mitochondria were numerous throughout the cytoplasm in both sham-control and treated Leydig cells. In mice, Mori et al. (1982) reported fractional volumes of $6.7 \%$ and $10.1 \%$ for SER and mitochondria, respectively. These values were in accordance with our data for the control animals. On the other hand, in mice treated with melatonin we observed an intense decrease in the fractional volume of these organelles. Zirkin et al. (1980) demonstrated that in many animals the SER is involved in steroid synthesis, and it is found in abundance in steroid-secreting cells like the Leydig cells. In these cells, the close association between enzymes and the SER, an important site involved in steroid biosynthesis (Wing et al., 1984), and the role of mitochondria in the cleavage of cholesterol, allow considering these organelles indicators of the synthetic activity of Leydig cells (Payne et al., 1996).

TABLE 1

Values of morphologic parameters obtained from Leydig cells of sham-control mice (group I) and those treated with $100 \mu \mathrm{g}$ of melatonin during 22 consecutive days (group II).

\begin{tabular}{|l|c|c|}
\hline \multicolumn{1}{|c|}{ Analyzed parameters } & Group I & Group II \\
\hline Nuclear volume $\left(\mu \mathrm{m}^{3}\right)$ & $110.20 \pm 5.76$ & $87.41 \pm 6.91 *$ \\
\hline Fractional volume of nucleus $(\%)$ & $24.81 \pm 0.66$ & $21.01 \pm 0.60 * *$ \\
\hline Fractional volume of cytoplasm $(\%)$ & $75.18 \pm 0.66$ & $78.98 \pm 0.60 * *$ \\
\hline Cytoplasmic volume $\left(\mu \mathrm{m}^{3}\right)$ & $302.04 \pm 12.25$ & $345.90 \pm 8.47 *$ \\
\hline Fractional volume of SER (\%) & $5.03 \pm 0.52$ & $1.71 \pm 0.17 * * *$ \\
\hline Fractional volume of RER $(\%)$ & $0.99 \pm 0.04$ & $0.69 \pm 0.06^{* *}$ \\
\hline Fractional volume of mitochondria $(\%)$ & $10.12 \pm 0.37$ & $7.32 \pm 0.47 * *$ \\
\hline Fractional volume of Golgi complex $(\%)$ & $0.48 \pm 0.02$ & $0.18 \pm 0.01 * * *$ \\
\hline Fractional volume of lysosomes $(\%)$ & $0.24 \pm 0.05$ & $0.79 \pm 0.01 * * *$ \\
\hline Fractional volume of lipid droplets $(\%)$ & $5.05 \pm 0.40$ & $5.91 \pm 0.92$ \\
\hline
\end{tabular}

Values are presented as the mean and standard error of mean; $n=5$ animals/group.

* $\quad$ Significant differences $(\mathrm{p}<0.05)$.

** Significant differences $(\mathrm{p}<0.01)$.

$* * *$ Significant differences $(\mathrm{p}<0.001)$. 


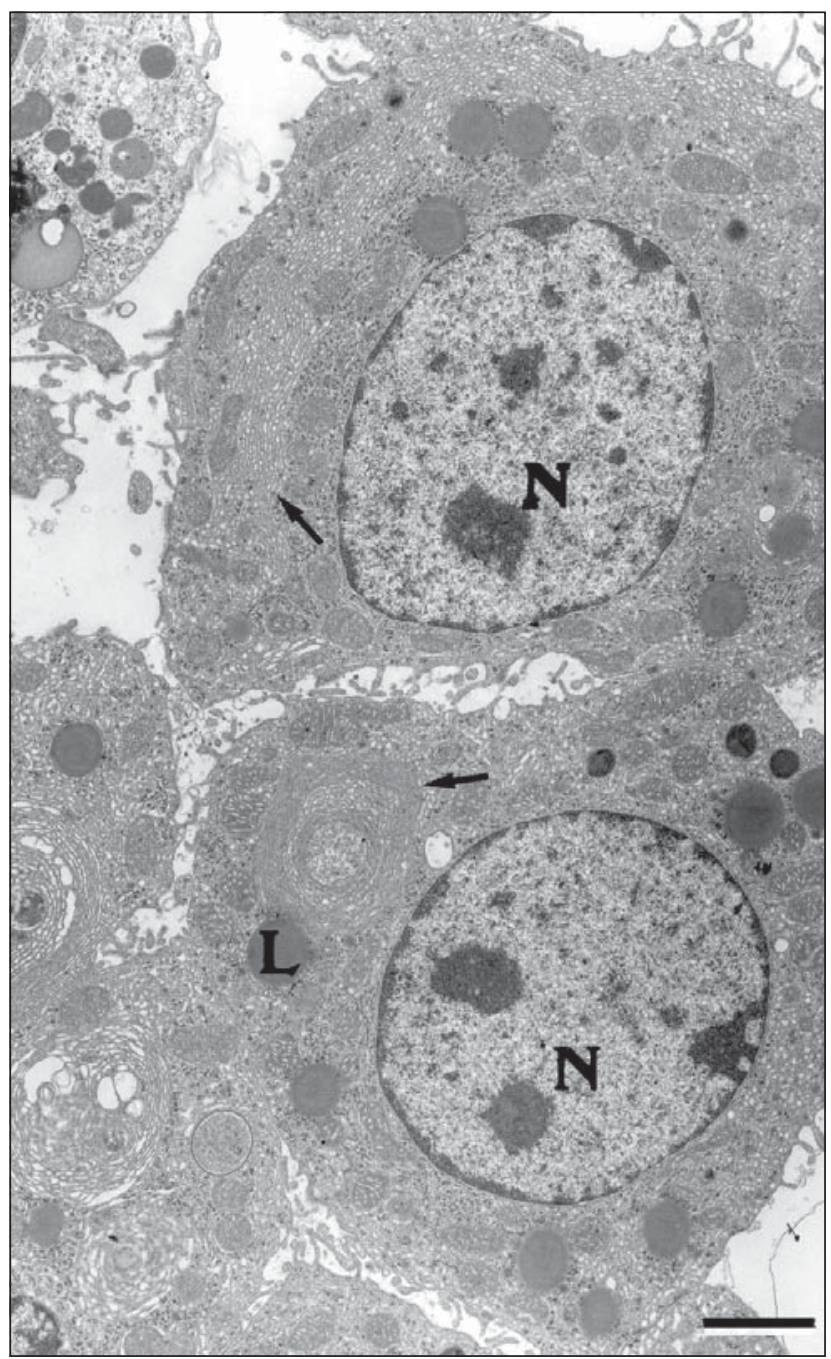

Fig. 2 - An electron micrograph of a sham-control mouse Leydig cell showing a prominent smooth endoplasmic reticulum which often is continuous with membrane whorls, sometimes extensively coiled (arrows). $\mathrm{N}=$ cell nucleus; $\mathrm{L}=$ lipid droplet. Bar $=2 \mu \mathrm{m}$.

Thus, our results suggest a diminishment of synthetic activity in Leydig cells in mice treated with melatonin. The fractional volumes of $0.6 \%$ and $0.3 \%$ for the rough endoplasmic reticulum (RER) and Golgi complex, respectively, observed in mouse Leydig cells and reported by Mori et al. (1982), were somewhat lower than those we estimated for the sham-control animals. According to Palade (1975) the RER and the Golgi complex are engaged in synthesis of secretory proteins for export from the cell. As do many secreting cells, the Golgi complex of Leydig cells participates in the secretory pathway of glycoproteins (Lalli \&
Clermont, 1975). Based on these reports, our results suggest that protein synthesis may be diminished in Leydig cells of mice treated with melatonin.

The lysosomal fractional volume that we detected in sham-control mice is much smaller than the $1.3 \%$ (of the cell volume) reported by Mori et al. (1982). According to Dunn, Jr. (1994) the mechanisms involved in the delivery of intracellular compounds to the lysosomes have been characterized in several recent studies and the sequestration of intracellular macromolecules for intralysosomal degradation can occur by autophagy in a phenomenon regulated by nutrients or hormones. 


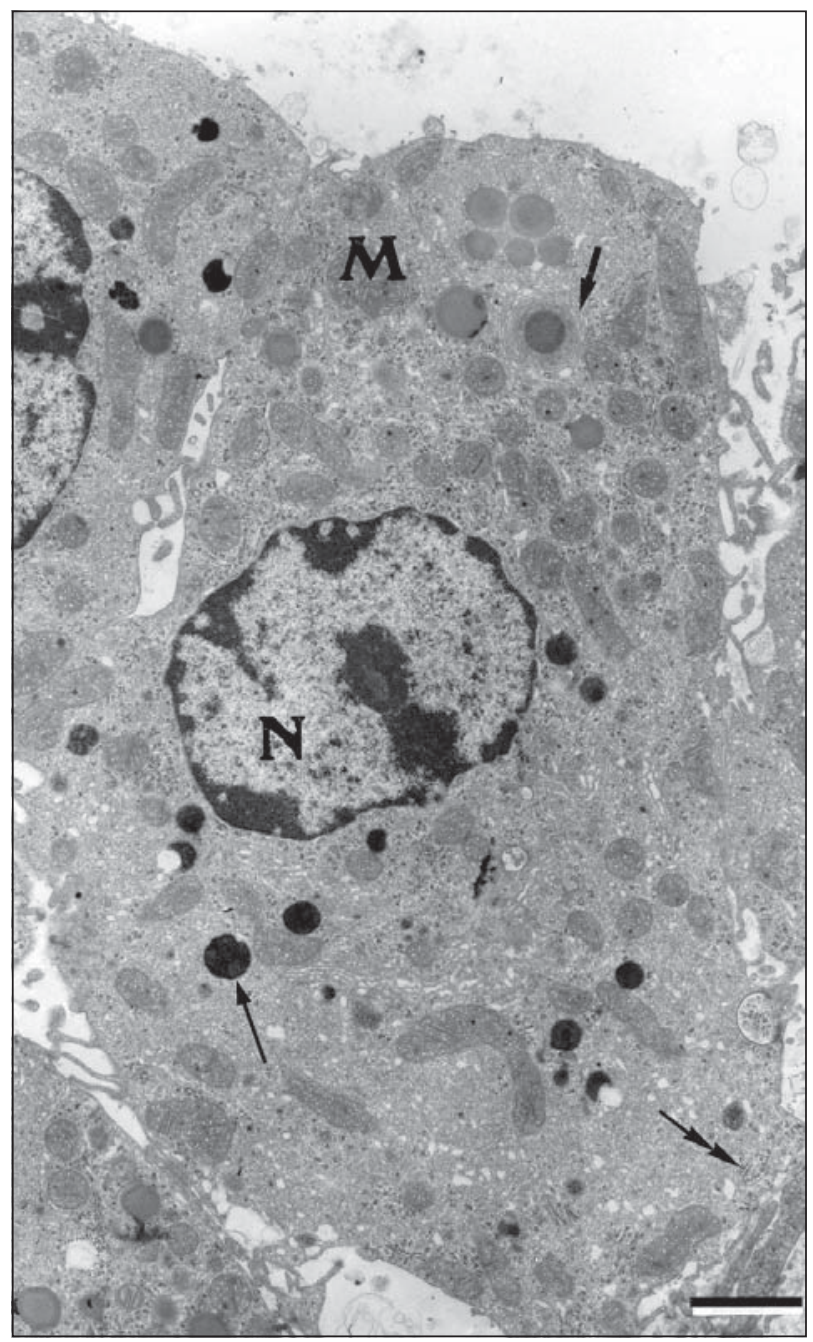

Fig. 3 - An electron micrograph of a melatonin treated mouse Leydig cell. $\mathrm{N}=$ cell nucleus; $\mathrm{M}=$ mitochondria; thin arrow $=$ lysosome; thick arrow $=$ smooth endoplasmic reticulum; double arrow $=$ rough endoplasmic reticulum. Bar $=2 \mu \mathrm{m}$.

Thus, in Leydig cells of mice treated with melatonin the lysosomes should be involved in controlling the synthesis and release of secretory products. In mice pinealocytes treated with melatonin, we noticed an apparent inhibition of the secretory activity of the pineal gland as well as an increase in lysosome number and fractional volume (Redins et al., 2001).

It is well-established that in Leydig cells, including mice Leydig cells (Ohata, 1979), lipid droplets are present in variable amounts and sometimes appear as small vacuoles in the cyto- plasm due to lipid extraction during tissue processing for microscopy. In sham-control and melatonin-treated mice we observed that Leydig cells have numerous lipid droplets which occupy $5.05 \%$ and $5.91 \%$ of the cell volume, respectively. These fractional volumes are quite similar to those reported by Mori et al. (1982).

Our morphologic results show that in Leydig cells of mice treated with melatonin, a decrease apparently occurs in the synthesis of steroids and proteins, coupled with an increase in the autophagy phenomena (crinophagy). 
Acknowledgments - The authors are grateful to the Center for Electron Microscopy, Institute of Biological Sciences, UFMG, and to CNPq for financial support.

\section{REFERENCES}

BASSI, W. E., HERNANDES, R., STIPP, A. C. M. \& TAGA, R., 1992, Avaliação morfométrica das dimensões do sistema de ductos estriados de glândulas parótidas do rato. Rev. Brasil. Ciên. Morfol., 9(1): 15-19.

BOZZOLA, J. J. \& RUSSEL, L. D., 1992, Quantitative Electron Microscopy. In: Principles and techniques for biologists. Jones and Bartlett Publishers, Boston, pp. 278304.

CHRISTENSEN, A. K., 1959, The fine structure of interstitial tissue of rat testes at various ages and after experimental treatment. Anat. Rec., 133: 367-368.

DUNN Jr., W. A., 1994, Autophagy and related mechanisms of lysosome-mediated protein degradation. Trends in Cell Biology, 4: 139-143.

FERREIRA, R. R., de ASSIS, G. F. \& TAGA, R., 1994, Estudo morfométrico da evolução do volume nuclear e citoplasmático e da relação citoplasma/núcleo de células acinosas de glândulas parótidas do rato durante a vida pós-natal. Rev. Brasil. Ciên. Morfol., 11(2): 1142-1148.

KUS, I., SARSILMAZ, M., OGETURK, M., YILMAZ, B., KELESTIMUR, H. \& ONER, H., 2000, Ultrastructural interrelationship between the pineal gland and the testis in the male rat. Arch. Androl., 45: 119-124.

LALLI, M. F. \& CLERMONT, Y., 1975, Leydig cells and their role in the synthesis and secretion of glycoproteins. Anat. Rec., 181: 403-404.

LANG, U., RIVEST, R. W., SCHLAEPFER, L. V., BRADTKE, J. C., AUBERT, M. L. \& SIZOENKO, P. C., 1984, Diurnal rhythm of melatonin action on sexual maturation of male rats. Neuroendocrinology, 38: 261268

MENDIS-HANDAGAMA, S. M. L. C., KERR, J. B. \& KRETSER, D. M., 1991, Experimental cryptorchidism in the adult mouse: III. Qualitative and quantitative electron microscopic morphology of Leydig cells. J. Androl., 12: 335-343.

MENDIS-HANDAGAMA, S. M. L. C., WATKINS, P. A., GELBER, S. J. \& SCALLEN, T. J., 1992, Leydig cell peroxisomes and sterol carrier protein-2 in luteinizing hormone-deprived rats. Endocrinology, 131: 2839-2845.

MORI, H., SHIMIZU, D., FUKUNISHI, Y. \& CHRISTENSEN, A. K., 1982, Morphometric analysis of testicular Leydig cells in normal adult mice. Anat. Rec., 204: $333-339$

NIEDZIELA, M., LERCHL, A. \& NIESCHLAG, E., 1995, Direct effects of the pineal hormone melatonin on testosterone synthesis of Leydig cells in Djungarian hamsters (Phodopus sungorus) in vitro. Neuroscience Letters, 201: 247-250.
NOVAES, J. C., REDINS C. A. \& CARVALHO, R. D., 1998, The effects of castration on the dense-core vesicles and lysosomes of pinealocytes in adult mice: a quantitative study. Braz. J. morphol. Sci., 15(1): 3-7.

OHATA, M., 1979, Electron microscopic study on the testicular interstitial cells of the mouse. Arch. Histol. Japan., 42: 51-79.

PALADE, G., 1975, Intracellular aspects of the process of protein synthesis. Science, 189: 347-358.

PAYNE, A. H., HARDY, M. P. \& RUSSEL, L. D., 1996, The Leydig cell. Vienna, Cache River Press, 802p.

REDINS, C. A., NOVAES, J. C., LIMA, M. T. V. \& GOMES, G. E., 1997, Ultrastructural comparison of pineal secretory rudimentary photoreceptor cells in Crypturellus parvirostris (Aves: Tinaniformes) during breeding and resting periods: a quantitative study. Rev. Brasil. Biol., 57(3): 521-529.

REDINS, C. A., NOVAES, J. C. \& TORRES, K. B., 1999, The effects of testosterone on the mice pinealocytes: a quantitative study. Tissue \& Cell, 31(2): 233-239.

REDINS, G. M., REDINS, C. A. \& NOVAES, J. C., 2001, The effect of treatment with melatonin upon the ultrastructure of the mouse pineal gland: a quantitative study. Braz. J. Biol., 61: 1-6.

VALENTI, S., GUIDO, R., GIUSTI, M. \& GIORDANO, G., 1995, In vitro acute and prolonged effects of melatonin on purified rat Leydig cell steroidogenesis and adenosine 3',5' monophosphate production. Endocrinology, 136: 5357-5362.

VALENTI, S., GIUSTI, M., GUIDO, R. \& GIORDANO, G., 1997, Melatonin receptors are present in adult rat Leydig cells and are coupled through a pertussis toxin-sensitive G-protein. European J. Endocrinology, 136: 633-639.

WING, T. Y., EWING, L. L. \& ZIRKIN, B. R., 1984, Effects of luteinizing hormone withdrawal on Leydig cell smooth endoplasmic reticulum and steroidogenic reaction which convert pregnenolone to testosterone. Endocrinology, 115: 2290-2296.

WU, C. S., LEU, S. F., YANG, H. Y. \& HUANG, B. M., 2001, Melatonin inhibits the expression of steroidogenic acute regulatory protein and steroidogenesis in MA-10 cells. J. Androl., 22: 245-254.

ZIRKIN, B. R., EWING, L. L., KROMANN, N. \& COCHRAN, R. C., 1980, Testosterone secretion by rat, rabbit, guinea pig, dog and hamster testes perfused in vitro: correlations with Leydig cell ultrastructure. Endocrinology, 107: 1867-1874. 